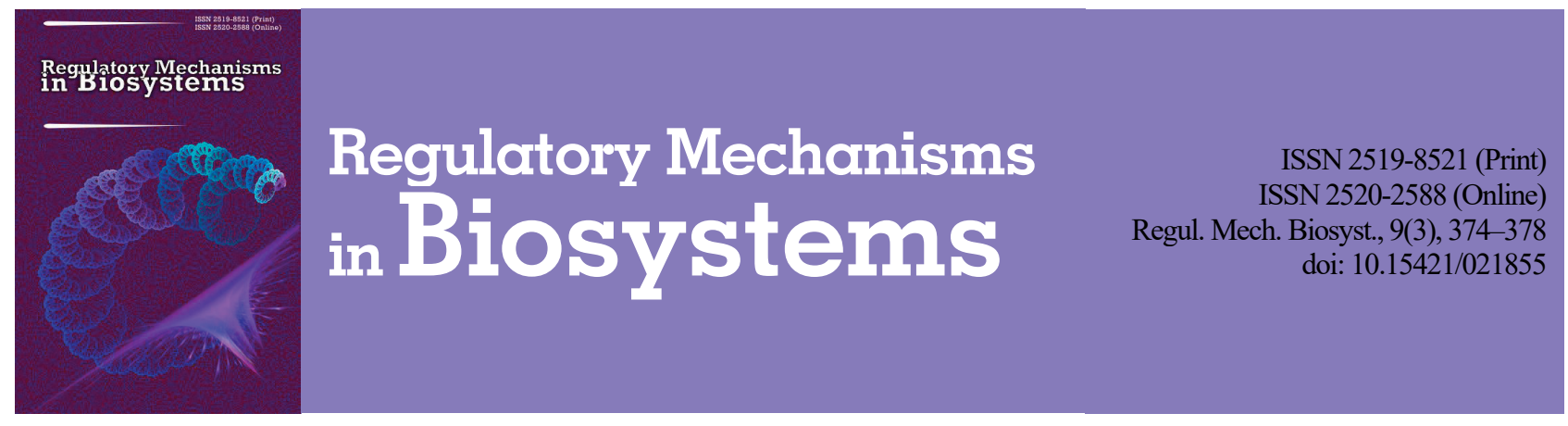

\title{
Antimicrobial activity of phytoextracts on opportunistic oral bacteria, yeast and bacteria from probiotics
}

\author{
N. M. Vorobets*, M. V. Kryvtsova**, O. Y. Rivis**, \\ M. Y. Spivak ***, H. V. Yavorska****, H. M. Semenova***** \\ *Danylo Halytsky Lviv National Medical University, Lviv, Ukraine \\ **Uzhhorod National University, Uzhhorod, Ukraine \\ ***Danylo Zabolotny Institute of Microbiology and Virology, National Academy of Sciense of Ukraine, Kyiv, Ukraine \\ ****Ivan Franko Lviv National University, Lviv, Ukraine \\ *****Bacteriological Laboratory of Uzhhorod District Hospital, Uzhhorod, Ukraine
}

Article info

Received 03.08.2018

Received in revised form 27.08.2018

Accepted 29.08.2018

Danylo Halytsky Lviv National Medical

University, Pekarska st., 69, Lviv, 79010, Ukraine.

Uzhhorod National University, Voloshyna st.

32, Uzhhorod, 88000, Ukraine.

Tel.: + 38-050-278-54-97.

E-mail:maryna.krivcova@gmail.com

Danylo Zabolotny Institute of Microbiology and Virology, National Academy of Sciense of Ukraine, Acad. Zabolotny st., 154, Kyiv, D03680, Ukraine.

Ivan Franko Lviv National University, Hrushevskyst., 4, Lviv, 79004, Ukraine.

Bacteriological Laboratory of Uzhhorod District Hospital, Mynajska st., 71, Uzhhorod, 88000, Ukraine.
Vorobets, N. M., Kryvtsova, M. V., Rivis, O. Y., Spivak, M. Y., Yavorska, H. V., \& Semenova, H. M. (2018). Antimicrobial activity of phytoextracts on opportunistic oral bacteria, yeast and bacteria from probiotics. Regulatory Mechanisms in Biosystems, 9(3), 374-378. doi:10.15421/021855

Developed experimental assays enable us to compare the antimicrobial activity of herbal medicinal drugs on Lactobacillus and Bacillus strains probiotics, which have been claimed to possess the ability of suppressing the growth of various oral pathogens. In the treatment of periodontal disease it is advisable to use a comprehensive approach which would include the application of herbal remedies and probiotics. The combination of such effects may be a new approach in dentistry due to their complementary antimicrobial activity. In this study, we researched antimicrobial effects of herbal medicinal drugs (tinctures of some medical plants, solutions Rotocanum and Chlorophyllipt) against collection strains and clinical strains isolated from the oral cavity of patients with periodontitis, and probiotic strains Bacillus subtilis UKM B-5007 and Bacillus licheniformis UKM B-5514 that are part of the active base of probiotic Biosporin (Ukraine), Bacillus clausii from the probiotic Normaflore (Hungary), as well as the strains Lactobacillus spp. - from probiotic Lactobacterinum (Biopharma, Ukraine). For investigation, the standard agar dilution method was used in modification with glass cylinders. The results of the research showed that among the studied herbal medicinal remedies, tinctures of Eucalypthus viminalis, Mentha piperita and Chlorophyllipt had the strongest antimicrobial activity. Probiotic strains are also sensitive to herbal tinctures (except the tinctura of wormwood), which indicate the possibility of only consecutive usage (with an interval of time) of herbal remedies and probiotics in combination therapy in the treatment of periodontal diseases

Keywords: antimicrobial activity; herbal medicinal remedies; probiotics; periodontal diseases.

\section{Introduction}

Oral health influences the general quality of life, and poor oral health is linked to chronic conditions and systemic diseases. Dental caries, gingivitis and periodontitis are prominent oral disorders. The current understanding is that the etiology of oral diseases is multifactorial but, in many cases, it includes a pathogenic response to bacterial and Candida infection (Radulovic et al., 2013; Vorobets \& Rivis, 2017). Periodontitis is a common and widespread disease, which occurs due to pathogenic microbial infection established within the gingival sulcus. Treatment of patients with periodontal diseases should include both local and general therapy. It must be based on the understanding of the mechanisms of action of the pharmaceutical or prophylactic agents, and be used to be effective and at the same time safe for the patient. Currently, the drugs of plant origin correspond to such criteria, because active compounds in their composition can act bacteriostatically and bactericidally (Rios et al., 2005; Kačániováa et al., 2014; Hleba et al., 2016). Another group of medicines - probiotics have relatively recently started to be used for periodontal treatment. Probiotics are commonly bacteria from genera Lactobacillus (including strains $L$. salivarius and L. plantarum) and Bifidobacterium (including strains $B$. bifidum, B. longum) or others, which could be beneficial not only to the digestive system, but to oral health too (Mishra et al., 2014; Alok et al., 2017).

The mechanisms of probiotic action are mainly unknown but the inter-microbial species interactions are supposed to play a key role in this together with their immunostimulatory effects. The proposed mechanisms of action of probiotics on oral health correspond to those shown in studies of the gastrointestinal tract. These are aid in synthesis of vitamins $\mathrm{B}$, and $\mathrm{K}$, and also in the breakdown of bile salts, aid in enhancing innate and acquired immunity, and assistance in inhibition of pro-inflammatory mediators (Alok et al., 2017). It is known that oral diseases, including periodontitis, are often accompanied by qualitative and quantitative changes in the microbiota (Rivis et al., 2012; Curtis, 2014). This makes probiotics an alternative means of correction of microbiota of the mouth and of reducing the number of opportunistic pathogens. On the other hand, there is evidence that the occurrence of candidiasis of the oral cavity and its chronic form is caused not only by changes in the balance of microorganisms in the mouth, but also by the influence of intestinal microbiota (Zlatkina et al., 2001).

Therefore, a complex treatment should be performed targeting the mouth and lower parts of the gastrointestinal tract. Dysbacteriosis is not only excessive growth of pathogenic microbes in the gut, but also 
involves the overall decline of the immune defence of the body (Alok et al., 2017) At the same time, it can involve such diseases as atopic dermatitis, eczema, thirst, bronchial asthma, food allergy in children. To restore normal intestinal microbiota, probiotics can be used, which are often composed of bifidobacteria and lactobacilli, which are able to show antagonism against pathogenic and opportunistic microorganisms. The results of our previous studies indicate that some industrial strains of spore bacteria that are used as a basis for probiotic products show high antagonistic activity against strains of microorganisms isolated from "periodontal pockets" (Rivis et al., 2013). However, from the clinical practitioner's point of view, direct recommendations for the use of probiotics cannot yet be given (Curtis, 2014). Beside this, there is a lack of information regarding the contributions of probiotics in oral health and their compatible use with plant origin remedies (Safronova, 2009; Shipradeep, 2012). Our research is focused on the determining of the antimicrobial properties of Tinctura Eucalypti, Tinctura Calendulae, Tinctura Menthae piperitae, Tinctura Absinthii, and also Tinctures Chlorophyllipt and Rotocanum against collection and clinical strains isolated from the oral cavity of patients with periodontitis and against probiotic strains that are part of the active base of probiotics Biosporin, Lactobacterin and Normaflore.

\section{Material and methods}

The effect of herbal medicinal products such as Rotocanum, Chlorophyllipt, Tinctura Calendulae, Tinctura Eucalipti, Tinctura Menthae piperitae, Tinctura Absinthii was investigated on collection and clinical isolated strains of microorganisms. The general chemical profiles of the extracts and their pharmacological effects against oral cavity diseases are summarized in Table 1.

To determine the antimicrobial activity of the herbal medicinal remedies, as test cultures we used bacteria from the American Type Culture Collection, USA: Escherichia coli ATCC 25922, Staphylococcus aureus ATCC 25923, Enterococcus faecalis ATCC 29212, and yeast Candida albicans ATCC 885-653; clinical strains of bacteria: Staphylococcus aureus, Streptococcus salivarius, Enterobacter sp., Neisseria sp.; yeast Candida albicans, isolated from the oral cavity of periodontitis patients; and bacteria Bacillus subtilis UKM B-5007 and Bacillus licheniformis UKM B-5514, isolated from probiotic Biosporin (Biopharma, Ukraine), and Bacillus clausii from the probiotic Normaflore (Manufacturer: Uniter Laboratory, France; holder of Sanofi-aventis S.p.A., Hungary trade license), as well as the strains Lactobacillus spp. - from probiotic Lactobacterinum (Biopharma, Ukraine). Positive control were prepared with the same solvents, which were used to prepare the plant Tinctures. The antiseptic drug Decasan (Solution of decamethoxine dihydrochloride $0.02 \%$ by weight in water with sodium chloride, Yuria-Pharm Ltd.) also has antimicrobial properties.

The agar diffusion method as adapted earlier using glass cylinders (Vorobets \& Yavorska, 2016) was used. From the daily culture of microorganisms, a suspension was made in a sterile physiological solution, and every suspension was adjusted to equal $0.5 \mathrm{McF}$ arland standard. Each cup of Muller-Hinton agar was filled with $0.1 \mathrm{ml}$ of a bacterial suspension. The cups were dried at room temperature for an hour. Then on the culture medium with tweezers we carefully arranged sterile glass cylinders, into which $0.1 \mathrm{ml}$ of the substance was contributed. Antimicrobial activity was judged by the presence and size of the growth zone of the studied microorganisms around the cylinder with the extract. To determine the antimicrobial activity of the examined samples, the following scale was used: diameter of the growth retardation zone more than $20 \mathrm{~mm}$ highly sensitive, $10-20 \mathrm{~mm}$ - sensitive, up to $10 \mathrm{~mm}$ - moderately sensitive. Ethanol of various concentrations was used as solvent control. All tests were performed at least three times.

Results of laboratory tests were processed by methods of variation statistics with the calculation of averages $(M)$ and their error $(m)$, the criterion of authenticity difference is determined using Fisher tables and adapted to the Medical Research simplified tables.

Table 1

Characteristics of Drugs Used

\begin{tabular}{|c|c|c|}
\hline $\begin{array}{c}\text { Latin name of the drug. } \\
\text { Manufacturer }\end{array}$ & $\begin{array}{c}\text { Active substance. } \\
\text { Extractant }\end{array}$ & $\begin{array}{r}\text { Pharmaceutical com } \\
\text { basic active substa }\end{array}$ \\
\hline $\begin{array}{l}\text { Tinctura Eucalypti. } \\
\text { LLC "DKP } \\
\text { "Pharmaceutical Factory", } \\
\text { Zhytomyr, Ukraine }\end{array}$ & $\begin{array}{l}\text { Eucalypti viminalis folia } \\
\text { Extractant } 70 \% \text { ethanol }\end{array}$ & $\begin{array}{l}\text { Eucalyptus leaves contai } \\
\text { oil }(3 \%) \text {, flavonoids, tanr } \\
\text { acid, resins and waxes }\end{array}$ \\
\hline $\begin{array}{l}\text { Tinctura Calendulae. } \\
\text { LLC "DKP } \\
\text { "Pharmaceutical Factory", } \\
\text { Zhytomyr, Ukraine }\end{array}$ & $\begin{array}{l}\text { Calendulae officinalis floridis } \\
\text { Extractant } 70 \% \text { ethanol }\end{array}$ & $\begin{array}{l}\text { Saponins, tannins, flavon } \\
\text { carotenoid glycosides, or } \\
\text { essential oil, carbohydrat } \\
\text { saponins, organic acids }\end{array}$ \\
\hline $\begin{array}{l}\text { Tinctura Menthae piperitae. } \\
\text { PrAT Pharmaceutical } \\
\text { Factory "Viola", } \\
\text { Zaporozhye, Ukraine }\end{array}$ & $\begin{array}{l}\text { Menthae piperitae folia } \\
\text { Extractant } 90 \% \text { ethanol }\end{array}$ & $\begin{array}{l}\text { Glycoside tropsolin, esse } \\
\text { menthol, potassium sulfa } \\
\text { phytosterols, ascorbic ac } \\
\text { starch, mucilage, pectin, } \\
\text { sorbuzin and others }\end{array}$ \\
\hline $\begin{array}{l}\text { Tinctura Absinthii } \\
\text { or Absinthii tinctura. } \\
\text { PrAT Pharmaceutical } \\
\text { Factory "Viola", } \\
\text { Zaporozhye, Ukraine } \\
\text { Chlorophyllipt. } \\
\text { Corporation "Arterium", } \\
\text { JSC "Halychpharm", } \\
\text { Lviv, Ukraine }\end{array}$ & $\begin{array}{l}\text { Extractum chlorophyllipti } \\
\text { spissum } \\
\text { Extractant } 96 \% \text { ethanol }\end{array}$ & $\begin{array}{l}\text { Chlorophylls mixture } \\
\text { of eucalyptus leaves }\end{array}$ \\
\hline $\begin{array}{l}\text { Rotocanum. } \\
\text { State Enterprise } \\
\text { "Experimental Plant of } \\
\text { Medicines IBONH NAS } \\
\text { of Ukraine", Kyiv, Ukraine }\end{array}$ & $\begin{array}{l}\text { A mixture of liquid extracts } \\
(2: 1: 1) \text { : Matricariae recutitae } \\
\text { extractum fluidum }+ \text { Calendulae } \\
\text { extractum fluidum }+ \text { Millefolii } \\
\text { extractum fluidum. } \\
\text { Extractant } 40 \% \text { ethanol }\end{array}$ & 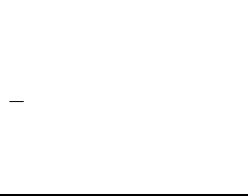 \\
\hline
\end{tabular}

\section{Results}

The antimicrobial activity of the herbal medicinal remedies was tested in vitro (Table 2). Tinctura Calendulae showed antimicrobial effect on
E. coli, S. aureus, E. faecalis, and probiotic strains. Moreover, such activity was greater than that of the antiseptic Decasan. However, it showed no or low antifungal activity and effects on bacteria of genus Neisseria and Enterobacter compared to controls. Research has shown 
that Tinctura Eucalipti has high antimicrobial activity against Grampositive, Gram-negative microorganisms, and probiotic strains. The diameters of zones of growth retardation were the highest for staphylococci (up to $30 \mathrm{~mm}$ ), streptococci (up to $30 \mathrm{~mm}$ ) and B. clausii (up to $40 \mathrm{~mm}$ ) and significantly exceeded the effect of Decasan on test culture. The tincture did not reveal a pronounced antifungal effect compared to the control. Tinctura Menthae piperitae produces using 90\% ethanol and Chloro-

Table 2

Antimicrobial activity of plant medicinal drugs to test-bacteria phyllipt $96 \%$ one, but despite the presence of the extractant revealed high antimicrobial activity of these drugs against Gram-positive microorganisms, so that diameters of growth were in the range of 20 to $40 \mathrm{~mm}$. These indicators significantly exceeded the effect of Decasan on test cultures. The Tinctura of peppermint inhibited the growth of Gram-negative microorganisms too. Phytopreparations of mint and Chlorophyllipt also have a high anti-candidal effect.

\begin{tabular}{|c|c|c|c|c|c|c|c|c|c|c|c|c|}
\hline $\begin{array}{l}\text { Plant medicinal } \\
\text { remedies }\end{array}$ & $\begin{array}{c}\text { C. albicans } \\
\text { ATCC } 885- \\
653\end{array}$ & $\begin{array}{c}\text { S. aureus } \\
\text { ATCC } \\
25923\end{array}$ & $\begin{array}{l}\text { E. faecalis } \\
\text { ATCC } \\
29212\end{array}$ & $\begin{array}{l}\text { E. coli } \\
\text { ATCC } \\
25922\end{array}$ & C. albicans & S. aureus & $\begin{array}{l}\text { Entero- } \\
\text { bacter } \text { sp. }\end{array}$ & Neisseria sp. & S. salivarius & $\begin{array}{c}\text { B. subtilis } \\
\text { UKM } \\
\text { B-5007, } B \text {. } \\
\text { lichenifor- } \\
\text { mis UKM } \\
\text { B-5514 } \\
\text { (Biosporin) }\end{array}$ & $\begin{array}{l}\text { B. clausii } \\
\text { (Norma- } \\
\text { flore) }\end{array}$ & $\begin{array}{c}\text { Lactobcillus } \\
\text { sp. } \\
\text { (Lactobac- } \\
\text { terinum) }\end{array}$ \\
\hline Tine & & & & & & & & & & 0 & & \\
\hline & & & & & & & & & & $3.5=$ & & \\
\hline Tinc & & & 3 & & & & & & & $26.0=$ & & 28 \\
\hline & & & & & & & & & & & & \\
\hline & & & & 10. & 11 & 13.3 & & ** 14.4 & 18.2 & $13.7 \pm$ & & \\
\hline $40 \%$ & 1.9 & 5.1 & $0.0 \pm$ & $0.0 \pm$ & $6.1 \pm 1.7$ & $0.0=$ & $0.0=$ & $6.0=$ & 0.0 & $0.0 \pm 0.0$ & $0.0 \pm 0.0$ & $0.0 \pm 0.0$ \\
\hline $\begin{array}{l}\text { Tinctura Menthae } \\
\text { piperitae }\end{array}$ & $35.7 \pm 2.7^{* *}$ & 2 & $\pm 1.3^{*}$ & $39.3 \pm 0.7^{* * *}$ & $0.5^{* \text { *wa }}$ & $\pm 1.3^{* *}$ & 27 & $\pm 1.0^{* *}$ & $.7^{*}$ & $26.4 \pm 4.4^{*}$ & 1 & $3^{*}$ \\
\hline & & & & & & & & & & & & \\
\hline Chlo & & & 37 & & & 34.8 & 19. & 32.0 & $35.0 \pm 2.7$ & $37.2 \pm 1.7^{* * * * *}$ & $40.4 \pm 1.2^{* * 4+1}$ & $39.3 \pm 0.7^{* * * *}$ \\
\hline $96 \%$ ethanol & $20.9 \pm 0.9$ & $22.4 \pm 0.8$ & $12.0 \pm 2.5$ & $23.3 \pm 2.4$ & $24.5 \pm 1.0$ & $19.2 \pm 0.7$ & $23.0 \pm 1.7$ & $18.4 \pm 0.6$ & $30.5 \pm 0.5$ & $6.0 \pm 0.3$ & $25.8 \pm 0.8$ & $26.0 \pm 0.0$ \\
\hline
\end{tabular}

Note: mathematical reliability ${ }^{*}-\mathrm{P}<0.05,{ }^{* *}-\mathrm{P}<0.01,{ }^{* * *}-\mathrm{P}<0.001$; the reliability of the difference between the plant medical remedies and the corresponding solution of alcohol P: Tinctura Absinthii, Tinctura Calendulae, Tinctura Eucalypti - 70\% ethanol; Rotocanum - 40\% ethanol; Tinctura Menthae piperitae $-90 \%$ ethanol; Chlorophyllipt $-96 \%$ ethanol.

Sensitive to the Tinctura Absinthii were $S$. salivarius $(19.6 \pm 0.9 \mathrm{~mm})$, E. faecalis $(16.5 \pm 0.6 \mathrm{~mm})$, and B. clausii $(21.3 \pm 1.3 \mathrm{~mm})$ from the probiotic Normaflore, as well as C. albicans, $S$. aureus and Lactobacillus sp., but ethanol also had an effect on these microorganisms. Tinctura Absinthii did not affect the growth of Gram-negative microorganisms, and species of probiotic Biosporin. The drug Rotocanum, which contains in its composition extracts of chamomile, calendula and yarrow (Calendula officinalis floridis + Chamomillae recutitae floridis + Achillea millefolii herbae) and is used as applications or mouthparts baths for patients with periodontitis and stomatitis, did not significantly affect the microorganisms which have been studied. The largest growth retardation regions were observed for streptococci $(15.5 \pm 0.6 \mathrm{~mm}$ for $E$. faecalis ATCC 29212 and $18.2 \pm 1.0 \mathrm{~mm}$ S. salivarius), staphylococci (12-14 mm), and Neisseria sp. (14.4 $\pm 1.9 \mathrm{~mm})$.

It should also be noted that all remedies as extractants containing ethanol are known as disinfectants that also have antimicrobial properties. It was found that Tinctura Absinthii had no effect on bacteria that are the active Biosporin basis. However, it affected the most opportunistic microbes taken in the experiment.

\section{Discussion}

Detailed analysis of the impact of drugs on different types of microorganisms made it possible to find that no drug that would act the same way or have no effect on the growth of microorganisms. Thus, the results obtained show that use of herbal drugs in dentistry is promising, in particular to eliminate infectious processes in the mouth and suppression of vital activity of pathogenic and opportunistic microorganisms.

The subject of antimicrobial properties of essential oils and extracts from Artemisia L. species is very widely discussed (Erel et al., 2007; Massiha et al., 2013). Cha (2007) investigated the chemical composition and antibacterial activity of Artemisia iwayomogi essential oil against oral bacteria. The essential oil of the plant exhibited strong inhibitory effect against all obligate anaerobic bacteria tested, while its major compounds demonstrated various degrees of growth inhibition (Cha, 2007). In our study, ethanolic extract of Artemisiae absinthii herba showed moderate effect on the investigated strains. Sensitive to the Tinctura Absinthii were mainly Gram-positive oral bacteria and yeast while it did not affect the growth of Gram-negative microorganisms and probiotic strains B. subtilis UKM B-5007, B. licheniformis UKM B-5514. Moslemi et al. (2012) showed that topical application of A. absinthium extract on the infected wound sites in rat models produced significant antibacterial activity against $S$. aureus.

In the present study, Tinctura Calendulae showed antimicrobial effect on most Gram-positive, Gram-negative microorganisms and probiotic strains. Szakiel et al. (2008) found that oleanic acid isolated from marigold (Calendula officinalis) inhibited bacterial growth and survival, influenced cell morphology and enhanced the autolysis of Gram-positive bacteria, suggesting that bacterial envelopes are the target of its activity. Essential oil from Calendula officinalis was effective against 23 clinical fungi strains tested (Gazim et al., 2008). Other experimental data obtainned showed that methanol extract of $C$. officinalis petals exhibited better antibacterial activity than ethanol exstract. However, both extracts showed high antifungal activity in comparison with fluconazole (Efstratiou et al., 2012). In our research Tinctura Calendulae has shown no or low antifungal activity in comparison with control.

Among the studied herbal medicinal products, the strongest antimicrobial activity was found in Tinctura Eucalipti, Tinctura Menthae piperitae and Chlorophyllipt. Eucalyptus oil, which is known for its antibacterial, antiviral (Cermelli et al., 2007; Astani et al., 2009) and antifungal (Ashour, 2008) properties, and has a long history of use for the treatment of colds, flu, rhinitis, sinusitis and other respiratory tract diseases. The obtained results have shown that essential oils of the leaves of $E$. globulus have antimicrobial activity against Gram-negative bacteria (E. coli) as well as Gram-positive bacteria (S. aureus) (Bachir \& Benali, 2012). The effectiveness of eucalyptus oils on caries and periodontitis pathogens was also investigated. In particular, essential oils of Eucalyptus camaldulensis showed antibacterial activity against Streptococcus mutans and significantly retard its biofilm formation (Rasooli et al., 2009). Takarada et al. (2004) earlier showed that eucalyptus oil inhibited the growth of the following oral bacteria: Porphyromonas gingivalis, Actinobacillus actinomycetemcomitans, Fusobacterium nucleatum, Streptococcus mutans, Streptococcus sorbinus and also inhibited the adhesion of S. mutans (Takarada et al., 2004). The antifungal effect of eucalyptus essential oils has been investigated. Ashour et al. (2008) showed that essential oils of $E$. sideroxylon and $E$. torquata generally exhibited moderate to high antifungal activities againt Candida albicans, A. flavus and A. niger (Ashour et al., 2008). Agarwal et al. (2008) inves- 
tigated the ability of eucalyptus essential oil to suppress the formation of C. albicans biofilm. Takahashi et al. (2004) reported that extracts of $E u$ calyptus globulus, E. maculata and E. viminalis significantly inhibited the growth of six Gram-positive bacteria (Staphylococcus aureus, MRSA, Bacillus cereus, Enterococcus faecalis, Alicyclobacillus acidoterrestris, Propionibacterium acnes), and of a fungus (Trichophyton mentagrophytes), but they did not show strong antibacterial activity against Gramnegative bacteria (Escherichia coli, Pseudomonas putida) (Takahashi et al., 2004). In our findings, Gram-negative bacteria showed lower sensitivity to Tinctura Eucalipti than Gram-positive bacteria.

Our results showed that the Tinctura of peppermint inhibited the growth of Gram-positive, Gram-negative microorganisms and had a high anti-candidal effect. Caretto et al. (2010) also showed antimicrobial activity of hydroalcoholic extract of Mentha piperita L. against Candida spp. (C. albicans, C. tropicalis and C. glabrata). Shalayel et al. (2017) showed the potential antibacterial activity for Mentha piperita extracts against MDR $S$. pyogenes, E. faecalis, MRSA, MRSE and carbapenem-resistant $E$. coli, and Klebsiella pneumonia clinical isolates. Sujana et al. (2013) earlier demonstrated that the organic extracts of the leaves of the plant (Mentha piperita L.) possessed strong antibacterial activity against a range of pathogenic bacteria, such as Bacillus subtilis, Streptococcus pneumonia, Staphylococcus aureus, Escherichia coli, Proteus vulgaris and Klebsiella pneumonia (Sujana et al., 2013). The mint leaf methanolic extract showed considerable antimicrobial activity against human oral pathogens, such as: Escherichia coli, Acinetobacter sp., Staphylococcus aureus and two fungi such as Candida albicans, C. glabrata (Pramila et al., 2012). Miloš Nikolić et al. reported antimicrobial activity of essential oil of pepermint Mentha piperita against pathogenic microorganisms isolated from the oral cavity ( 8 bacteria and 58 Candida $\mathrm{sp.)}$ and referent strains (Nikolić et al., 2013).

According to usage instruction, Chlorophyllipt inhibits staphylococci infections that are resistant to antibiotics and is used in washing, rinsing, lotion, wet tampons and douching, and in dental stomatitis to treat gangrenous pulpitis, abscesses, boils, inflammation of the oral mucosa. Our results suggested its antibiotic activity not only against collection and clinical strains of Gram-positive and Gram-negative bacteria, but also against investigated probiotic strains. By investigation of the antagonistic activity of probiotics it was established that bacteria, being the background of the biopreparations, have demonstrated different levels of suppression effect on various strains of test-cultures.

\section{Conclusions}

It was confirmed that each of the proposed health benefits should be studied separately for each probiotic bacterial strain, especially if the treatment protocol stipulates the use of drugs with herbal remedies. At the same time, all probiotic strains proved to be sensitive to the action of plant extracts, indicating the possibility of consecutive use (with an interval of time) of herbal remedies and probiotics in combination therapy for the treatment of periodontal disease. Screening herbal medicinal products according to their activity on the Lactobacillus and Bacillus strains of probiotics could precede the clinical efficacy studies for adjunct treatment with both in treatment of periodontal infections.

While BAS of herbal medicines suppress the vital activity of pathogenic and opportunistic microorganisms or destroy them, probiotics create conditions for the resumption of normal microbiota. Alternating drugs (of plant origin and probiotics) in the treatment of periodontal disease will prevent the formation of resistant strains of oral microbiota, and will not disturb the biological balance in the oral cavity, and, therefore, will provide recovery of the patient's health.

\section{References}

Agarwal, V., Lal, P., \& Pruthi, V. (2008). Prevention of Candida albicans biofilm by plant oils. Mycopathologia, 165(1), 13-19.

Alok, A., Singh, I. D., Singh, S., Kishore, M., Jha, P. C., \& Iqubal, M. A. (2017). Probiotics: A new era of biotherapy. Advanced Biomedical Research, 6(1), 31.

Ashour, H. M. (2008). Antibacterial, antifungal and anticancer activities of volatile oils and extracts from stems, leaves, and flowers of Eucalyptus sideroxylon and Eucalyptus torquata. Cancer Biology and Therapy, 7(3), 399-403.
Astani, A., Reichling, J., \& Schnitzler, P. (2009). Comparative study on the antiviral activity of selected monoterpenes derived from essential oils. Phytotherapy Research, 24(5), 673-679.

Bachir, R. G., \& Benali, M. (2012). Antibacterial activity of the essential oils from the leaves of Eucalyptus globulus against Escherichia coli and Staphylococcus aureus. Asian Pacific Journal of Tropical Biomedicine, 2(9), 739-742.

Carretto, C. F. P., Junqueira, J. C., Almeida, R. B. A., Furlan, M. R., \& Jorge, A. O. C. (2010). Antimicrobial activity of Mentha piperita L. against Candida spp. Brazilian Dental Science, 13(1/2), 4-9.

Cermelli, C., Fabio, A., Fabio, G., \& Quaglio, P. (2007). Effect of eucaliptus essential oil on respiratory bacteria and viruses. Current Microbiology, 56(1), 89-92.

Cha, J.-D. (2007). Chemical composition and antibacterial activity against oral bacteria by the essential oil of Artemisia iwayomogi. Journal of Bacteriology and Virology, 37(3), 129-136.

Curtis, M. A. (2014). Periodontal microbiology - The lid's off the box again. Journal of Dental Research, 93(9), 840-842.

Efstratiou, E., Hussain, A. I., Nigam, P. S., Moore, J. E., Ayub, M. A., \& Rao, J. R. (2012). Antimicrobial activity of Calendula officinalis petal extracts against fungi, as well as Gram-negative and Gram-positive clinical pathogens. Complementary Therapies in Clinical Practice, 18(3), 173-176.

Erel, Ş. B., Yavaoğlu, N. Ü. K., \& Zeybek, U. (2007). Antimicrobial activities of six artemisia species of West Anatolia. Planta Medica, 73(9), 131.

Gazim, Z. C., Rezende, C. M., Fraga, S. R., Estivaleti Svidzinski, T. I., \& Garsia Cortez, D. A. (2008). Antifungal activity of the essential oil from Calendula officinalis L. (Asteraceae) growing in Brazil. Brazilian Journal of Microbiology, 39(1), 61-63.

Hleba, L., Kompas, M., Hutková, J., Rajtar, M., Petrová, J., Čuboň, J., Kántor, A., \& Kačániová, M. (2016). Antimicrobial activity of crude ethanolic extracts from some medicinal mushrooms. Journal of Microbiology, Biotechnology and Food Sciences, 5(1), 60-63.

Kačániováa, M., Vukovic, N., Horska, E., Salamov, I., Bobkova, A., Hleba, L., Mellen, M., Vatlak, A., Petrova, J., \& Bobko, M. (2014). Antibacterial activity against Clostridium genus and antiradical activity of the essential oils from different origin. Journal of Environmental Science and Health, Part B, 49(7), 505-512.

Massiha, A., Majid Khoshkholgh-Pahlavian, M., Issazadeh, K., Bidarigh, S., \& Zarrabi, S. (2013). Antibacterial activity of essential oils and plant extracts of Artemisia (Artemisia annua L.) in vitro. Zahedan Journal of Research in Medical Sciences, 15(6), 14-18.

Mishra, R., Tandon, S., Rathore, M., \& Banerjee, M. (2014). Antimicrobial and plaque inhibitory potential of herbal and probiotic oral rinses in children: A randomized clinical trial. Indian Journal of Dental Research, 25(4), 485-492.

Moslemi, H. R., Hoseinzadeh, H., Badouei, M. A., Kafshdouzan, K., \& Fard, R. M. (2012). Antimicrobial activity of Artemisia absinthium against surdical wounds infected by Staphylococcus aureus in a rat model. Indian Journal of Microbiology, 52(4), 601-604.

Nikolić, M., Glamočlija, J., Ćirić, A., Marković, T., Marković, D., Perić, T., \& Soković, M. (2013). Hemijski sastav i antimikrobna aktivnost etarskog ulja pitome nane (Mentha piperita L.). Lekovite Sirovane, 33, 63-72.

Pramila, D. M., Xavier, R., Marimuthu, K., Kathiresan, S., Khoo, M. L., Senthilkumar, M., Sathya, K., \& Sreeramanan, S. (2012). Phytochemical analysis and antimicrobial potential of methanolic leaf extract of peppermint (Mentha piperita: Lamiaceae). Journal of Medicional Plants Research, 6(2), 331-335.

Radulovic, N. S., Blagojevic, P. D., Stojanovic-Radic, Z. Z., \& Stojanovic, N. M. (2013). Antimicrobial plant metabolites: Structural diversity and mechanism of action. Current Medicinal Chemistry, 20(7), 932-952.

Rios, J. L., \& Recio, M. C. (2005). Medicinal plants and antimicrobial activity. Journal of Ethnopharmacology, 100, 80-84.

Rasooli, I., Shayegh, S., \& Astaneh, S. D. A. (2009). The effect of Mentha spicata and Eucalyptus camaldulensis essentisl oils on dental biofilm. International Journal of Dental Hygiene, 7(3), 196-203.

Rivis, O. Y., Krivtsova, M. V., Nikolaichuk, V. I., Semenova, G. M., \& Barani, E. A. (2012). Mikroflora rotovoi' porozhnyny ljudej z zapal'nymy zahvorjuvannjamy tkanyny parodontu $\mathrm{v}$ Uzhgorods'komu rajoni [Microflora of the oral cavity of people with inflammatory diseases of periodontal tissue in Uzhgorod area]. Bulletin of Problems in Biology and Medicine, 1(3), 121124 (in Ukrainian).

Rivis, O. Y., Krivtsova, M. V., \& Nikolaichuk, V. I. (2013). Antagonistic activity of Bacillus probiotics against bacteria isolates of oral cavity of patients with periodontitis. Visnyk of Dnipropetrovsk University. Biology, Medicine, 4(1), 10-13.

Safronova, L. A., Osadchaya, A. I., Avdeyeva, L. V., \& Ilyash, V. M. (2009). Vlijanie fitokompozicij na biologicheskuju aktivnost' probioticheskih shtammov $\mathrm{Ba}$ cillus subtilis. [Influence of phytocompositions on biological activity of Bacillus subtilis probiotic strains]. Likarska Sprava, 3-4, 68-74 (in Russian).

Shalayel, M. H. F., Asaad, A. M., Qureshi, M. A., \& Elhussein, A. B. (2017). Anti-bacterial activity of peppermint (Mentha piperita) extracts against some emerging multi-drug resistant human bacterial pathogens. Journal of Herbal Medicine, 7, 27-30. 
Shipradeep, K. S., Khare, R. S., Ojha, S., Kundu, K., \& Kundu, S. (2012). Development of probiotic candidate in combination with essential oils from medicinal plant and their effect on enteric pathogens: a review. Gastroenterology Research and Practice, 2012, 1-6.

Shulga, L. I. (2011). Fitopreparaty v stomatologii': Suchasnyj stan ta perspektyvy stvorennja [Herbal remedies in dentistry: Current status and perspectives for production]. Clinical Pharmacy, Pharmacotherapy and Medical Standardization, 3-4, 151-156 (in Ukrainian)

Sujana, P., Sridhar, T. M., Josthna, P., \& Naidu, C. V. (2013). Antibacterial activity and phytochemical analysis of Mentha piperita L. (Peppermint) - An important multipurpose medicinal plant. American Journal of Plant Sciences, 4(1), 77-83.

Szakiel, A., Ruszkowski, D., Grudniak, A., Kurek, A., Wolska, K. I., Doligalska, M., \& Janiszowska, W. (2008). Antibacterial and antiparasitic activity of oleanolic acid and its glycosides isolated from marigold (Calendula officinalis) Planta Medica, 74(14), 1709-1715.
Takahashi, T., Kokubo, R., \& Sakaino, M. (2004). Antimicrobial activities of eucalyptus leaf extracts and flavonoids from Eucalyptus maculata. Letters in Applied Microbiology, 39(1), 60-64.

Takarada, K., Kimizuka, R., Takahashi, N., Honma, K., Okuda, K., \& Kato, T. (2004). A comparison of the antibacterial efficacies of essential oils against oral pathogens. Oral Microbiology and Immunology, 19(1), 61-64.

Vorobets, N., \& Rivis, O. (2017). Aktual'nist' ta perspektyvy vykorystannja likars'kyh roslyn dlja likuvannja kandydozu rotovoi' porozhnyny [Relevance and perspectives of using medicinal plants for the treatment of oral candidiasis]. Bulletin of Problems in Biology and Medicine, 135, 22-32 (in Ukrainian).

Vorobets, N. M., \& Yavorska, H. V. (2016). Modifications of agar diffusion method to determination of the antimicrobial effect of the herbal medicinal products. Ukrainian Biopharmaceutical Journal, 43, 80-84.

Zlatkina, A. R., Isakov, V. A., \& Ivanikov, I. O. (2001). Kandidoz kishechnika kak novaja problema gastrojenterologii [Candidiasis of the intestine as a new problem of gastroenterology]. Russian Journal of Gastroenterology, Hepatology, Coloproctology, 6, 33-38 (in Russian). 